\title{
Water potential, biochemical indicators and yield of sugarcane irrigated with brackish water and leaching
}

\author{
Anízio H. Godoi Neto+, Ênio F. de F. e Silva ${ }^{1}$, José E. F. de Morais ${ }^{1}$, Larissa G. L. de Andrade ${ }^{1}$, \\ Weliston de O. Cutrim ${ }^{1} \&$ Claudivan F. de Lacerda ${ }^{2}$ \\ ${ }^{1}$ Universidade Federal Rural de Pernambuco/Departamento de Engenharia Agrícola/Programa de Pós-Graduação em Engenharia Agrícola, Recife, PE, Brasil. \\ E-mail: agrohonorato@gmail.com - ORCID: 0000-0003-4714-6763; enio.fsilva@ufrpe.br - ORCID: 0000-0002-8652-503X; joseedson50@hotmail.com \\ (Corresponding author) - ORCID: 0000-0002-3641-2221; larissa_lino_03@hotmail.com - ORCID: 0000-0002-0025-5471; weliston_cutrim@hotmail.com - \\ ORCID: 0000-0002-3929-4355 \\ ${ }^{2}$ Universidade Federal do Ceará/Departamento de Engenharia Agrícola. Fortaleza, CE, Brasil. E-mail: cfeitosa@ufc.br - ORCID: 0000-0002-5324-8195
}

\begin{abstract}
Knowledge on the water relations and biochemical responses of plants has been pointed out as important for selecting genotypes that are tolerant to abiotic stresses, such as drought and salinity. Thus, the objective of this study was to evaluate the leaf water potential, enzymatic activity and yield of sugarcane (RB 92579) irrigated with brackish waters and leaching fractions. The study was conducted from November 2016 to November 2017 in Recife, PE, Brazil. The experimental design was completely randomized, in a $5 \times 2$ factorial scheme, with four repetitions. Treatments consisted of five irrigation water salinity $(0.5 ; 2.0 ; 4.0 ; 6.0$ and 8.0

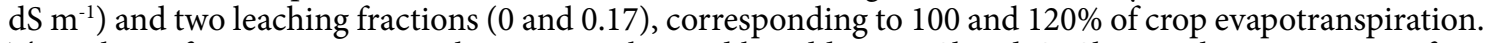
The values of irrigation water salinity were obtained by adding $\mathrm{NaCl}$ and $\mathrm{CaCl}_{2}$ at molar proportion of $1: 1$ $(\mathrm{Ca}: \mathrm{Na})$ to water from the local supply $\left(\mathrm{ECw}=0.5 \mathrm{dS} \mathrm{m}^{-1}\right)$. Readings of leaf water potential $(\Psi \mathrm{w})$ were taken at predawn, and +3 leaves were collected for the determination of catalase and ascorbate peroxidase activity at 90, 150, 210 and 270 days after planting. Yield was determined at 365 days after planting. Increase in water salinity reduced leaf water potential and yield, and increased the activity of catalase and ascorbate peroxidase, and the leaching fraction of 0.17 was able to reduce the deleterious effects of salts on plants.
\end{abstract}

Key words: Saccharum spp., oxidative stress, salinity, leaching fraction

\section{Potencial hídrico, indicadores bioquímicos e produtividade da cana-de-açúcar irrigada com águas salobras e lixiviação}

RESUMO: O conhecimento das relações hídricas e das respostas bioquímicas de plantas tem sido apontado como importante para a seleção de genótipos tolerantes aos estresses abióticos, tais como seca e salinidade. Assim, objetivou-se avaliar o potencial hídrico foliar, atividade enzimática e produtividade da cana-de-açúcar (RB 92579) irrigada com águas salobras e frações de lixiviação. A pesquisa foi conduzida no período de novembro 2016 a novembro 2017 em Recife, PE, Brasil. Adotou-se o delineamento experimental inteiramente casualizado, em esquema fatorial $5 \times 2$, com quatro repetições. Os tratamentos consistiram de cinco salinidades da água de irrigação $\left(0,5 ; 2,0 ; 4,0 ; 6,0\right.$ e $\left.8,0 \mathrm{dS} \mathrm{m^{-1 }}\right)$ e duas frações de lixiviação $(0$ e 0,17$)$, correspondendo a 100 e $120 \%$ da evapotranspiração da cultura. Os valores de salinidade da água de irrigação foram obtidos pela adição de $\mathrm{NaCl}$ e $\mathrm{CaCl}_{2}$ na proporção de 1:1 molar (Ca:Na) na água de abastecimento $(\mathrm{CEa}=0,5 \mathrm{dS}$ $\left.\mathrm{m}^{-1}\right)$. Foram realizadas leituras do potencial hídrico foliar $\left(\Psi_{\mathrm{w}}\right)$ no antemanhã e coletadas folhas +3 para a determinação da atividade da catalase e da ascorbato peroxidase aos 90, 150, 210 e 270 dias após o plantio. A produtividade foi determinada aos 365 dias após o plantio. O aumento da salinidade da água reduziu o potencial hídrico foliar e o rendimento, e, aumentou a atividade da catalase e ascorbato peroxidase, sendo a fração de lixiviação de 0,17 capaz de reduzir os efeitos deletérios dos sais sobre as plantas.

Palavras-chave: Saccharum spp., estresse oxidativo, salinidade, fração de lixiviação 


\section{INTRODUCTION}

Brazil is the world's largest producer of sugarcane, one of the most efficient bioenergy sources. In the Northeast region, crops are concentrated on the coast (CONAB, 2018), where the presence of brackish waters due to saline intrusion is common. Thus, the use of brackish waters and/or inadequate management of the soil-water-plant system can cause damage to plant physiology and yield in irrigated areas (Munns \& Tester, 2008; Herbert et al., 2015).

Salt accumulation reduces the osmotic potential of the soil solution and water availability, and the specific ionic effects resulting from the absorption of toxic ions $\left(\mathrm{Na}^{+}\right.$and $\left.\mathrm{Cl}^{-}\right)$ interfere in the absorption of nutrients and cause cytotoxicity (Mansour, 2014).

In order to adapt to the excess of salts in the root environment, plants reduce leaf water potential to maintain a favorable gradient for water absorption and flow in the soil-root-shoot system, a process that most often increases metabolic energy expenditures (Negrão et al., 2017; Taiz et al., 2017).

Salt stress, especially at moderate to severe levels, causes a secondary stress called oxidative stress, capable of generating accumulation of reactive oxygen species (ROS) and damage to membranes and macromolecules. At the cellular level, however, plants have developed mechanisms capable of neutralizing the damage caused by ROS (Carvalho et al., 2016). Among these mechanisms, antioxidant enzymes such as ascorbate peroxidase (APX), catalase (CAT) and superoxide dismutase (SOD) stand out (Anitha et al., 2015; Ferreira et al., 2017).

Considering that the literature is scarce with respect to studies on sugarcane crop under salt stress (Endres et al., 2010; Anitha et al., 2015; Carvalho et al., 2016), the objective was to evaluate the leaf water status, activity of enzymes of the antioxidative protection system and yield along the cultivation cycle of sugarcane (RB 92579) irrigated with brackish waters and leaching fractions.

\section{Material ANd Methods}

The experiment was conducted at the Prof. Ronaldo Freire de Moura Lysimetric Station of Irrigated Agriculture, located at the Department of Agricultural Engineering (DEAGRI) of the Universidade Federal Rural de Pernambuco (UFRPE), Recife, $\mathrm{PE}$, Brazil, whose geographical coordinates are $8^{\circ} 1^{\prime} 6^{\prime \prime} \mathrm{S}$ and $34^{\circ} 56^{\prime} 49^{\prime \prime} \mathrm{W}$, and altitude of $6 \mathrm{~m}$.

The total area used has dimensions of $32 \times 75 \mathrm{~m}(2400$ $\mathrm{m}^{2}$ ), being located in the central part of a lysimetric station $(18 \times 25.80 \mathrm{~m})$ composed of 40 drainage lysimeters $\left(1 \mathrm{~m}^{3}\right)$ installed equidistantly at $1.20 \mathrm{~m}$, in both directions, and an automatic meteorological station (Campbell Scientific CR1000 model) used to obtain climatic data for irrigation management.

The lysimeters were filled with soil (0-0.40 m layer) from the municipality of Goiana, PE, Brazil, classified as a Spodosol Orthod in the classification of U.S. Soil Taxonomy (Soil
Survey Staff, 2014). Its physical-chemical characteristics are: sand, silt and clay $=890,30$ and $80 \mathrm{~g} \mathrm{~kg}^{-1}$, respectively; textural class = sand; soil density $=1.73 \mathrm{~kg} \mathrm{dm}^{-3}$; particle density $=2.63 \mathrm{~kg} \mathrm{dm}^{-3}$; volumetric moisture $(0.33 \mathrm{~atm})$ $=3.02 \%$; volumetric moisture $(15 \mathrm{~atm})=1.34 \%$; organic matter $=15.35 \mathrm{~g} \mathrm{~kg}^{-1} ; \mathrm{pH}_{(\mathrm{H} 2 \mathrm{O})}=6.5 ; \mathrm{P}=49 \mathrm{mg} \mathrm{dm}^{-3} ; \mathrm{K}^{+}=$ $0.08 \mathrm{cmol} \mathrm{cm}^{-3} ; \mathrm{Ca}^{+}=1.6 \mathrm{cmol} \mathrm{dm}_{\mathrm{c}}^{-3} ; \mathrm{Mg}^{2+}=0.65 \mathrm{cmol}_{\mathrm{c}} \mathrm{dm}^{-3}$; $\mathrm{Na}^{+}=0.06 \mathrm{cmol}_{c} \mathrm{dm}^{-3} ; \mathrm{H}^{+}+\mathrm{Al}^{3+}=3.05 \mathrm{cmol}_{c} \mathrm{dm}^{-3} ; \mathrm{Al}^{3+}=0$ $\mathrm{cmol}_{c} \mathrm{dm}^{-3}$; cation exchange capacity $=5.4 \mathrm{cmol}_{c} \mathrm{dm}^{-3}$; base saturation $=44 \%$; and aluminum saturation $=0 \%$.

According to the recommendation of fertilization for the state of Pernambuco, Brazil (Cavalcanti et al., 2008), basal mineral fertilization was performed with $20 \mathrm{~kg} \mathrm{ha}^{-1}$ of $\mathrm{N}, 40 \mathrm{~kg} \mathrm{ha}^{-1}$ of $\mathrm{P}_{2} \mathrm{O}_{5}$ and $35 \mathrm{~kg} \mathrm{ha}^{-1}$ of $\mathrm{K}_{2} \mathrm{O}$. At 45 and 150 days after planting (DAP), topdressing fertilization was performed applying $20 \mathrm{~kg}$ $\mathrm{ha}^{-1}$ of $\mathrm{N}$ and $35 \mathrm{~kg} \mathrm{ha}^{-1}$ of $\mathrm{K}_{2} \mathrm{O}$. Application of micronutrients was performed through leaf fertilization, applying $1.3 \mathrm{~kg} \mathrm{ha}^{-1}$ of $\mathrm{Cu}, 2.0 \mathrm{~kg} \mathrm{ha}^{-1}$ of $\mathrm{Zn}$ and $2.6 \mathrm{~kg} \mathrm{ha}^{-1}$ of $\mathrm{Mn}$.

The sugarcane variety RB 92579 was planted on November 19, 2016, using six cuttings per linear meter, with two buds each, and performing a thinning after emergence to keep 8 plants $\mathrm{m}^{-1}$.

Treatments consisted of the combination of five irrigation water salinity $\left(\mathrm{ECw}=0.5 ; 2.0 ; 4.0 ; 6.0\right.$ and $\left.8.0 \mathrm{dS} \mathrm{m}^{-1}\right)$ and the conditions without $(\mathrm{LF} 1=0)$ and with leaching fraction $(\mathrm{LF} 2=$ 0.17 ), corresponding to 100 and $120 \%$ crop evapotranspiration (ETc). The experimental design used was completely randomized in $5 \times 2$ factorial scheme, with four repetitions.

Water salinity values were obtained by adding $\mathrm{NaCl}$ and $\mathrm{CaCl}_{2} \cdot \mathrm{H}_{2} \mathrm{O}$ (A.R.) at molar proportion of 1:1 (Ca: $\mathrm{Na}$ ) to the local supply water $\left(\mathrm{ECw}=0.5 \mathrm{dS} \mathrm{m}^{-1}\right)$, at concentrations necessary to obtain the pre-established values of electrical conductivity, according to Richards (1954), through Eqs. 1 and 2:

$$
\begin{aligned}
& \mathrm{Q}=640 \cdot \mathrm{ECw} \text { when } \mathrm{ECw}<5.0 \mathrm{dS} \mathrm{m}^{-1} \\
& \mathrm{Q}=800 \cdot \mathrm{ECw} \text { when } \mathrm{ECw}>5.0 \mathrm{dS} \mathrm{m}^{-1}
\end{aligned}
$$

where:

Q - quantity of salts, $\mathrm{mg} \mathrm{L}^{-1}$; and,

$\mathrm{ECw}$ - desired value of water electrical conductivity, $\mathrm{dS}^{-1}$.

Sodium and calcium chloride salts are some of the most frequently found salts in the irrigation water of the Northeast region, so the leaching fraction (0.17) associated with the drainage system were used as a strategy to mitigate the effects of salts on plants.

Treatments began to be applied at 60 DAP, with daily irrigations using the respective saline waters based on ETc, obtained by the product of reference evapotranspiration (ETo) and crop coefficient (Kc). ETo was estimated by the Penman-Monteith equation (Allen et al., 1998). The Kc used corresponds to the phenological stage of the plant, according to the United Nations Food and Agriculture Organization - FAO (Allen et al., 1998). Irrigation was applied by a drip system with pressure-compensating emitters, spaced at $0.30 \mathrm{~m}$ and with unit flow rate of $4.1 \mathrm{~L} \mathrm{~h}^{-1}$. 
The water depth received through rainfall over the period was $1774 \mathrm{~mm}$, but with water surplus in only one month in relation to crop demand (Figure 1). The reference evapotranspiration accumulated throughout the cultivation cycle was $1287.35 \mathrm{~mm}$ $\left(3.52 \mathrm{~mm} \mathrm{~d}^{-1}\right)$. The irrigation depths applied based on 100 and $120 \%$ ETc, corresponding to the leaching fractions LF1 $=0$ and LF2 $=0.17$, were 522.53 and $609.01 \mathrm{~mm}$, respectively.

At 90, 150, 210 and 270 days after planting - DAP, leaves were collected for analysis of leaf water potential $\left(\Psi_{\mathrm{w}}\right)$ by means of a Scholander-type pressure chamber (M1505D model, PMS Company). Readings were taken at predawn (before sunrise), by collecting one leaf per lysimeter, +3 leaf, which is the third visible leaf of the sheath known as TVD (Top Visible Dewlap) leaf, according to Kuijper (Dillewijn, 1952).

At 90, 150, 210 and 270 DAP, leaves (+3 leaf) were collected from the respective treatments to determine the activity of catalase (CAT) and ascorbate peroxidase (APX). These leaves were cut at the base, wrapped in aluminum foil, immersed in liquid nitrogen and immediately stored in ultra-freezer $(-80$ ${ }^{\circ} \mathrm{C}$ ) until the analytical procedure.

To obtain the enzymatic extract, $0.1 \mathrm{~g}$ of fresh matter was macerated in liquid nitrogen and received $4 \mathrm{~mL}$ of potassium phosphate buffer $(50 \mathrm{mM})$, with $\mathrm{pH} 7.0$ and Polyvinylpyrrolidone (PVP) to avoid oxidation of enzymes during the process. After maceration, the concentrate was filtered into 2-mL Eppendorf tubes and placed in refrigerated centrifuge for $10 \mathrm{~min}$ at $10,000 \mathrm{rpm}\left(4^{\circ} \mathrm{C}\right)$. Catalase activity was determined using the methodology proposed by Kar \& Mishra (1976), while ascorbate peroxidase was determined following the methodology of Nakano \& Asada (1981).

At 365 DAP, harvest was carried out and the stems were weighed to obtain the fresh biomass ( $\mathrm{TCH}, \mathrm{Mg} \mathrm{ha}^{-1}$ ).

The data were subjected to normality test, homoscedasticity test and analysis of variance by $\mathrm{F}$ test $(\mathrm{p} \leq 0.05)$ for each evaluation period. The values of salinity were compared through regression analysis and the leaching fractions were compared by Tukey test ( $\mathrm{p} \leq 0.05)$, using the statistical software SISVAR (Ferreira, 2011).

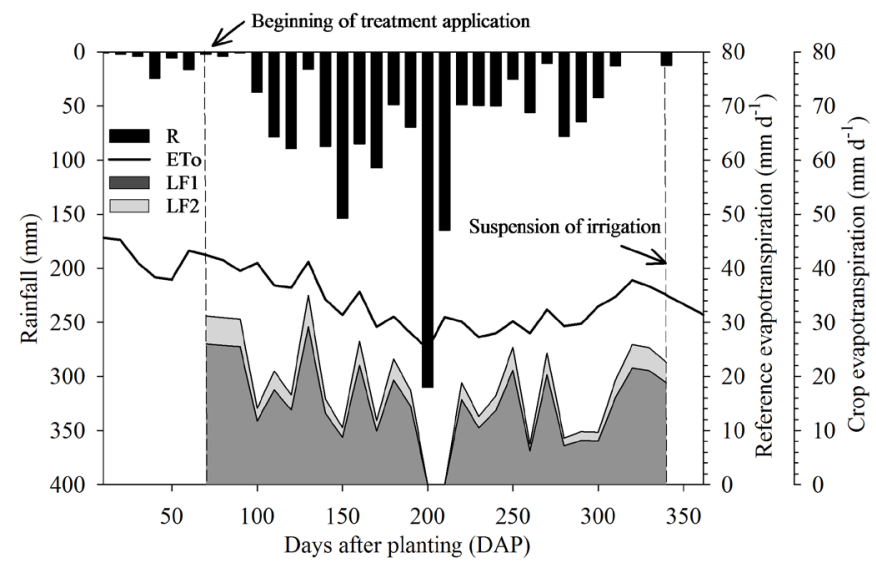

Figure 1. Rainfall, reference evapotranspiration and crop evapotranspiration for 10 -day periods throughout the cultivation cycle

\section{Results AND Discussion}

Figure 2 shows that the interaction between irrigation water electrical conductivity and irrigation depths had significant
A.

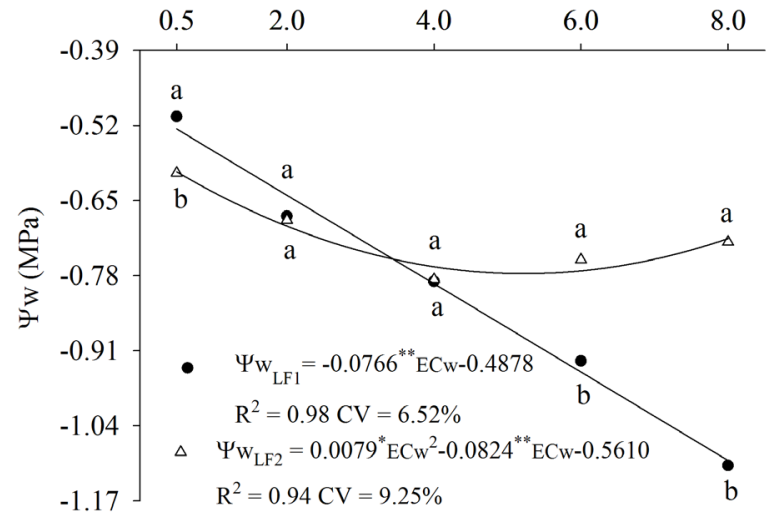

B.
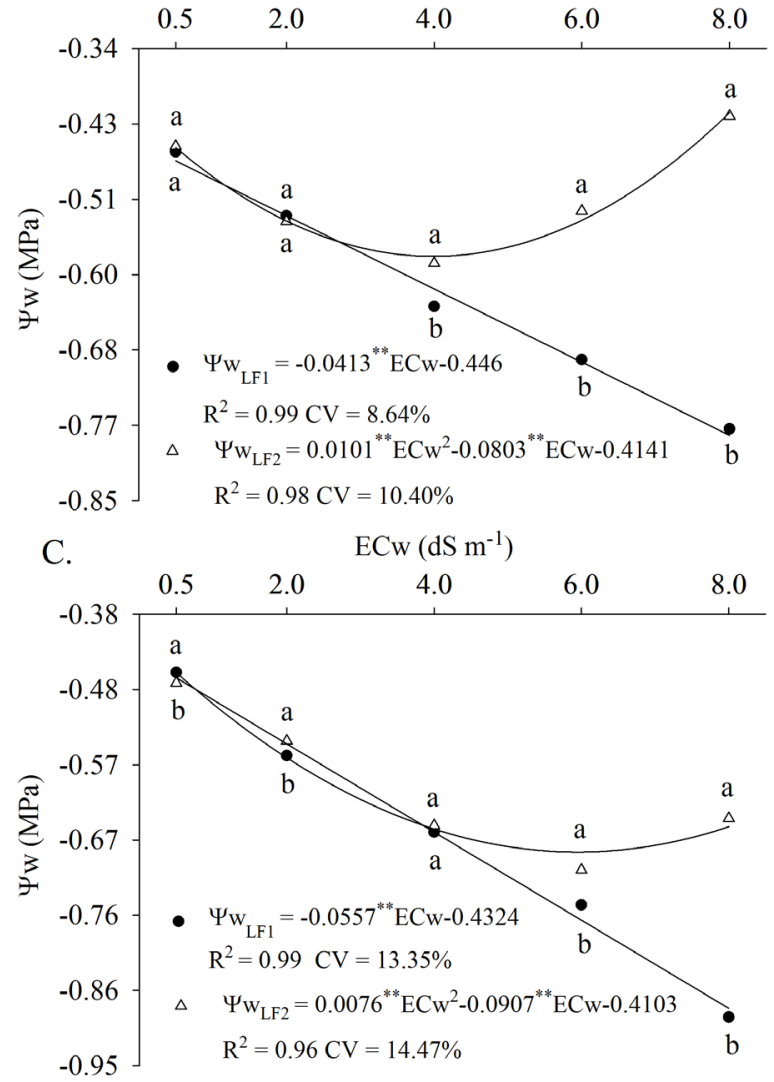

D.

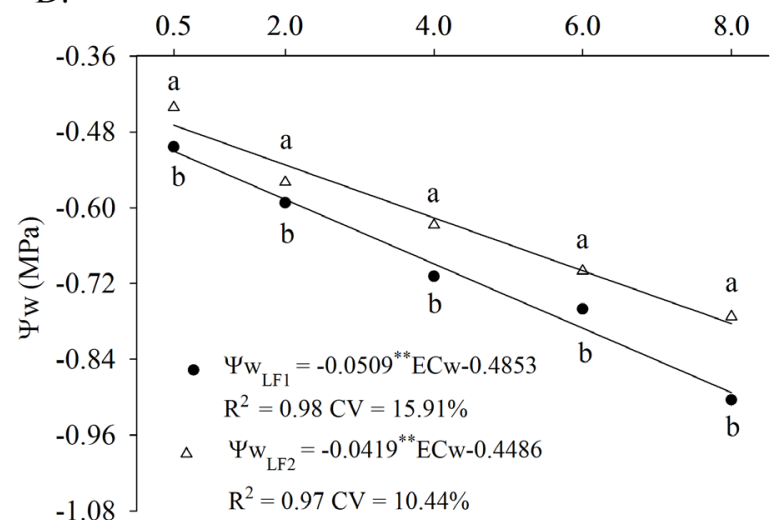

**, * - Significant at $\mathrm{p} \leq 0.01$ and 0.05 , respectively, by $\mathrm{F}$ test. The same letters indicate not significant difference $(\mathrm{p} \leq 0.05)$ in the conditions without (LF1) and with (LF2) leaching fraction

Figure 2. Leaf water potential of sugarcane (RB 92579), subjected to water salinity (ECw) at $90(\mathrm{~A}), 150$ (B), 210 (C) and 270 days after planting (D), without (LF1) and with (LF2) leaching fraction 
effects on the leaf water potential $\left(\Psi_{\mathrm{w}}\right)$ of plants. At 90 (Figure 2A), 150 (Figure 2B), 210 (Figure 2C) and 270 DAP (Figure $2 \mathrm{D})$, there was a linear reduction $(\mathrm{p} \leq 0.01)$ of $\Psi \mathrm{w}$ as a function of increasing salinity in the treatment without leaching fraction $(\mathrm{LF} 1=0)$. For the treatment with leaching fraction $(\mathrm{LF} 2=$ 0.17 ), the response was quadratic in the first three periods, with the values remaining higher than those of plants cultivated without leaching fraction (LF1) at the highest salinity levels.

At 90 DAP (Figure 2A), the mean values of $\Psi_{\mathrm{W}}$ observed for salinity levels of 0.5 and $8.0 \mathrm{dS} \mathrm{m} \mathrm{m}^{-1}$ were -0.53 and $-1.10 \mathrm{MPa}$, respectively, a percentage reduction of 109.2. In the treatment with leaching fraction of 0.17 , corresponding to the water depth of $120 \%$ ETc, there were mean values of -0.60 and $-0.78 \mathrm{MPa}$ in the interval of irrigation water salinity between 0.5 and 5.22 $\mathrm{dS} \mathrm{m}^{-1}$, respectively, a reduction of $29.26 \%$, remaining with values equal to or higher than $-0.72 \mathrm{MPa}$ at the highest levels of salinity. These results showed the efficiency of the leaching fraction in controlling salts in the soil, for the displacement of salts from irrigation water and/or those already existing in the soil to deeper areas than the root zone (Puga et al., 2016).

At 150 (Figure 2B) and 210 DAP (Figure 2C), there was a similar response to that observed at 90 DAP, but a 150 DAP the mean values of leaf water potential are probably due to the occurrence of rains in the period (Figure 1), which leached much of the salts from the root zone. This situation is consistent with the claim of Cavalcante et al. (2018), who concluded that the waters of the rainy season promoted the leaching of salts from the root environment of plants. The mean values observed for the treatment without leaching fraction at salinity levels of 0.5 and $8.0 \mathrm{dS} \mathrm{m}^{-1}$ were -0.47 and $-0.78 \mathrm{MPa}$, respectively, with a reduction of $66.38 \%$.

High salt concentrations at the root-soil interface reduce water absorption by the plant, because of the decrease in soil water potential, due to both osmotic and matric effects (Oliveira et al., 2018). In addition, the absorption of salts $\left(\mathrm{Na}^{+}\right.$and $\left.\mathrm{Cl}^{-}\right)$in excess induces toxicity due to the specific ionic effect, compromising the absorption of nutrients and photosynthesis (Munns \& Tester, 2008; Mansour, 2014).

Variations in $\Psi_{\mathrm{w}}$ indicate that the imposed level of salt stress varied not only with the water salinity and leaching fraction, but also with environmental conditions, especially with the occurrence of rains. This finding reinforces the importance of field trials, especially with perennial crops or crops with long cycles, such as sugarcane.

Studies conducted with well hydrated herbaceous plants have shown that $\Psi_{\mathrm{W}}$ ranges from -0.2 to close to $-0.9 \mathrm{MPa}$, and lower values indicate that plants are under moderate water stress (Taiz et al., 2017).

Endres et al. (2010), evaluating the sugarcane variety RB 92579 under water deficit in Coruripe, AL, Brazil, observed $\Psi_{\mathrm{W}}$ values of $-0.9 \mathrm{MP}$ to (moderate drought) and up to $-1.5 \mathrm{MPa}$ (severe water deficit). The results of $\Psi_{\mathrm{w}}$ show that the stress levels experienced by sugarcane were not severe, even at the highest levels of irrigation water salinity, and were lessened by the occurrence of rains and by the use of a leaching fraction of 0.17 .

At 270 DAP (Figure 2D), $\Psi_{\mathrm{W}}$ decreased linearly $(\mathrm{p} \leq 0.01)$ for both leaching fractions (100 and $120 \%$ ETc) with the increase in water salinity. In the treatment without leaching fraction, mean values of -0.51 and $-0.89 \mathrm{MPa}$ were recorded at 0.5 and $8.0 \mathrm{dS} \mathrm{m}^{-1}$, a percentage reduction of $74.74 \%$. Lira et al. (2018a) observed reductions of up to $66.28 \%$ in the $\Psi_{\mathrm{w}}$ of sugarcane (RB 867515) subjected to ECw of $6.5 \mathrm{dS} \mathrm{m}^{-1}$ without leaching fraction, at 318 DAP, in Recife, PE, Brazil.

The increase in water salinity increased the activity of catalase - CAT ( $\mathrm{p} \leq 0.01)$ up to the highest values of 602.81 and $613.64 \mu \mathrm{mol} \mathrm{H}_{2} \mathrm{O}_{2} \mathrm{mg}^{-1}$ protein $\mathrm{min}^{-1}$ in plants irrigated with $6.34 \mathrm{dS} \mathrm{m}^{-1}$ water at 150 (Figure $3 \mathrm{~A}$ ) and $7.01 \mathrm{dS} \mathrm{m}^{-1}$ water at
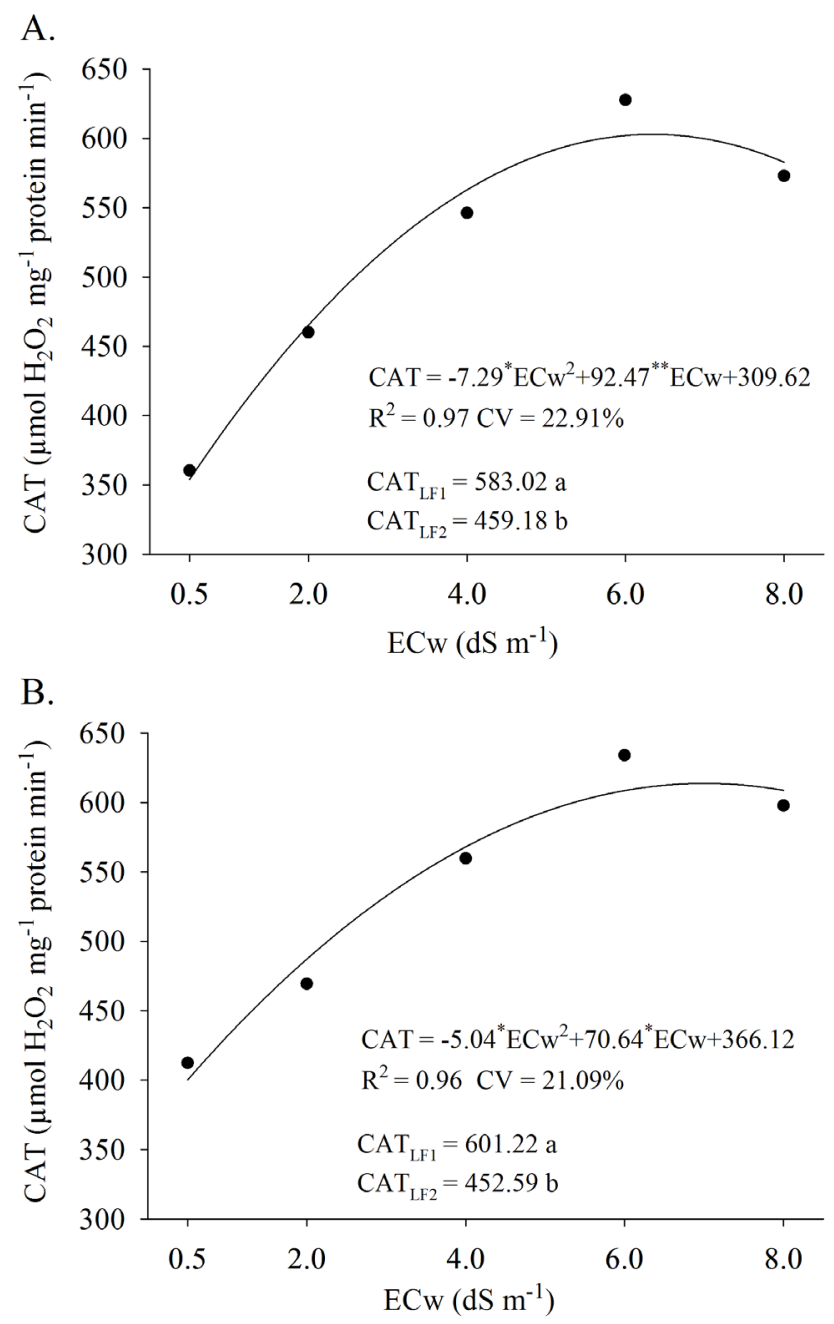

C.

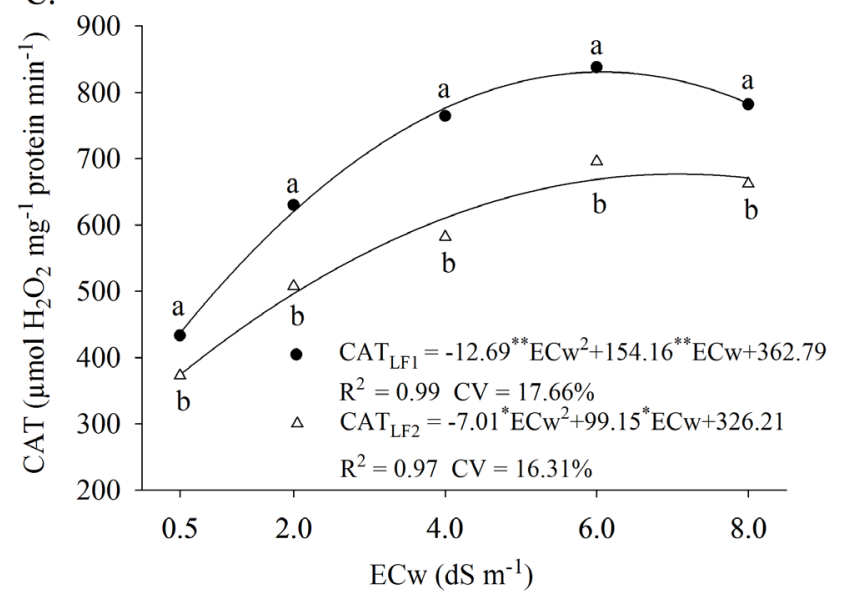

**, ${ }^{*}$ Significant at $\mathrm{p} \leq 0.01$ and 0.05 , respectively, by $\mathrm{F}$ test. The same letters indicate not significant difference $(\mathrm{p} \leq 0.05)$ in the conditions without (LF1) and with (LF2) leaching fraction

Figure 3. Catalase activity in sugarcane (RB 92579) subjected to water salinity (ECw) at 150 (A), 210 (B) and 270 days after planting (C), without (LF1) and with (LF2) leaching fraction 
210 DAP (Figure 3B), respectively. At 90 DAP, there was no significant difference $(p>0.05)$ between treatments.

These values indicate the saturation of the enzyme, evidencing that the response of this defense mechanism to oxidative stress is dependent on the level of salt stress imposed on the sugarcane crop. The results also indicate that, despite the modest decrease at the highest level of stress, the values exceed those observed in plants subjected to the lowest level of irrigation water salinity. According to Azevedo et al. (2011), the capacity of activation of the antioxidant system is one of the main mechanisms of adjustment of the plant to oxidative stress.

Figure 3C shows the effect of the interaction between irrigation water electrical conductivity and leaching fractions for catalase (at $270 \mathrm{DAP})$, with significant effect $(\mathrm{p} \leq 0.01)$ for the two leaching fractions ( 0 and 0.17 ). The mean values of catalase in plants irrigated with $100 \%$ ETc water depth were 436.70 and $830.98 \mu \mathrm{mol} \mathrm{H}_{2} \mathrm{O}_{2} \mathrm{mg}^{-1}$ protein $\mathrm{min}^{-1}$ relative to the waters with electrical conductivities of 0.5 and $6.07 \mathrm{dS} \mathrm{m}^{-1}$, respectively, promoting an increase of $90.29 \%$.

For the $120 \%$ ETc water depth, the maximum value (676.82 $\mu \mathrm{mol} \mathrm{H}_{2} \mathrm{O}_{2} \mathrm{mg}^{-1}$ protein $\mathrm{min}^{-1}$ ) was only observed at salinity of $7.07 \mathrm{dS} \mathrm{m}^{-1}$, but the values of catalase activity were significantly lower than those determined in plants irrigated with water depth of $100 \%$ ETc, regardless of water salinity level. These results indicate a lower degree of salinity-induced oxidative stress under conditions of use of leaching fraction.

Figure $3 \mathrm{~A}$ shows the mean values of catalase activity in sugarcane leaves (150 DAP) in response to the irrigation depths (LF1 and LF2). There was a significant increase ( $\mathrm{p} \leq 0.01)$ of $21.24 \%$ in catalase due to the pronounced effect of salt stress, with values of 583.02 and $459.18 \mu \mathrm{mol} \mathrm{H}_{2} \mathrm{O}_{2} \mathrm{mg}^{-1}$ protein $\mathrm{min}^{-1}$ corresponding to leaching fractions of 0 and 0.17 , respectively. Similar results were obtained at $210 \mathrm{DAP}$ (Figure 3B). The leaching fraction promoted greater removal of salts from the root system zone of the plants, reducing the intensity of salt stress.

Despite having low affinity for $\mathrm{H}_{2} \mathrm{O}_{2}$ when compared to APX, CAT has a very fast rate of peroxide degradation, being an important line of oxidative defense in plants under stress (Zhang et al., 2016; Fahad et al., 2017). This situation justifies the higher activity of the catalase enzyme in plants subjected to salt stress without leaching fraction in the present study.

The effect of interaction between irrigation water electrical conductivity and leaching conditions on the activity of ascorbate peroxidase (APX) can be observed at 150 (Figure 4A), 210 (Figure 4B) and 270 DAP (Figure 4C), with a significant quadratic effect $(\mathrm{p} \leq 0.01)$. There was no significant difference $(p>0.05)$ between treatments at 90 DAP.

At 150 DAP, without leaching fraction (Figure 4A), the maximum value $\left(34054.09 \mu \mathrm{mol}_{2} \mathrm{O}_{2} \mathrm{mg}^{-1}\right.$ protein $\left.\mathrm{min}^{-1}\right)$ was found at salinity of $7.27 \mathrm{dS} \mathrm{m^{-1 }}$, an increase of $95.87 \%$ compared to the lowest level of salinity $\left(0.5 \mathrm{dS} \mathrm{m} \mathrm{m}^{-1}\right)$. With the leaching fraction of 0.17 , there was a percentage increase in APX of $77.65\left(6.61 \mathrm{dS} \mathrm{m}^{-1}\right)$, demonstrating the efficiency of the leaching fraction (LF2) in alleviating the effects of salt stress.

In the three periods of evaluation (Figures $4 \mathrm{~A}, \mathrm{~B}$ and C), the behavior of APX activity is similar to that of catalase
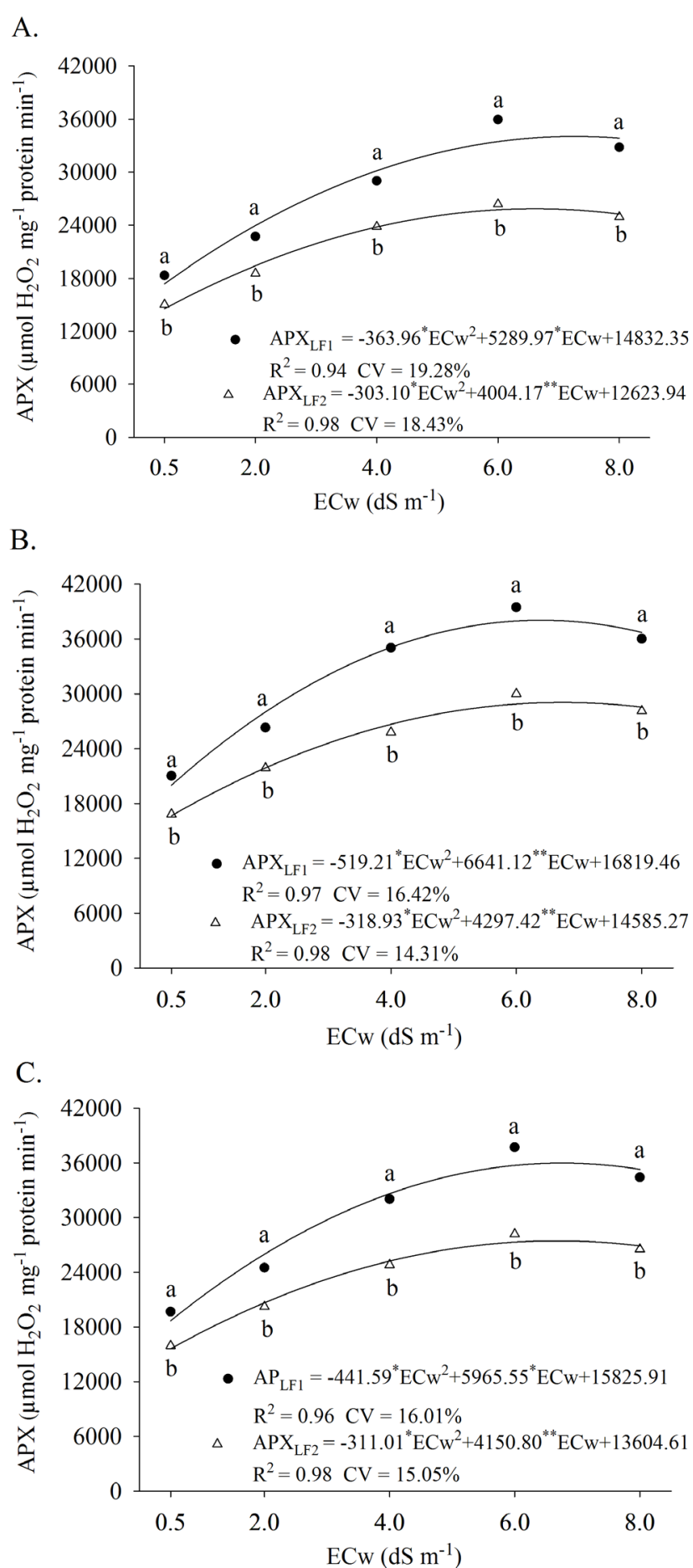

$* *,{ }^{*}$ Significant at $\mathrm{p} \leq 0.01$ and 0.05 , respectively, by $\mathrm{F}$ test. Values with the same letters indicate not significant difference $(\mathrm{p} \leq 0.05)$ in the conditions without (LF1) and with (LF2) leaching fraction

Figure 4. Ascorbate peroxidase in sugarcane (RB92579) subjected to water salinity (ECw) at 150 (A), 210 (B) and 270 days after planting (C), without (LF1) and with (LF2) leaching fraction

activity (Figure 3), exhibiting saturation of the response with the increase of salinity; however, APX activities were much higher than CAT activities in all periods and in all treatments.

Unlike SOD and CAT, ascorbate peroxidases use ascorbate (ASA) as an electron donor to convert $\mathrm{H}_{2} \mathrm{O}_{2}$ into $\mathrm{H}_{2} \mathrm{O}$ and $\mathrm{O}_{2}$ in several cell compartments such as chloroplasts, mitochondria, apoplast and cytosol (Nishiyama \& Murata, 2014). Also according to these authors, the APXs have a high affinity for 
peroxide, identifying it even at very low concentrations $(\mu \mathrm{M})$, unlike CATs, which can only identify it at higher levels (mM).

APX and CAT enzymes have the level of activity stabilized in plants irrigated with waters of higher salinity levels, but the values remain much higher than those observed in lower salinity treatments. This indicates that there is good potential for enzymes to degrade ROS and, consequently, mitigate the impacts of oxidative stress on cellular structures and functions. This does not mean, however, repairing all damage caused by salt stress, since oxidative degradation is only a secondary stress component associated with stress caused by excess of salts in the soil.

The results corroborate those of Carvalho et al. (2016) for the varieties RB 92579 and RB867515 subjected to salt stress with $\mathrm{NaCl}$ in the initial stage of growth, as these authors observed stabilization of enzymatic activity when water salinity reached values close to $6.0 \mathrm{dS} \mathrm{m}^{-1}$.

APX activity was lower in plants treated with leaching fraction (LF2), for all salinity levels and in all periods of evaluation (Figure 4). According to Anitha et al. (2015), the responses of plants to salt stress are complex, occurring in genetic networks and metabolic processes that depend on the inherent salt tolerance of the species, salt concentration and duration of exposure.

For TCH (Figure 5), the unit increase in salinity levels promoted reductions of 5.70 and $4.77 \mathrm{Mg} \mathrm{ha}^{-1}$ of stem fresh matter for the conditions without (LF1) and with (LF2) leaching fraction, respectively. The highest stem yield was obtained when LF2 was adopted at the salinity of $0.5 \mathrm{dS} \mathrm{m} \mathrm{m}^{-1}$ $\left(168.97 \mathrm{Mg} \mathrm{ha}^{-1}\right)$, while at the salinity level of $8.0 \mathrm{dS} \mathrm{m}^{-1}$ for this same condition, TCH was equal to $133.19 \mathrm{Mg} \mathrm{ha}^{-1}(-21.17 \%)$. In the condition of LF1, the obtained values of TCH were 130.76 and $88.01 \mathrm{Mg} \mathrm{ha}^{-1}$, for the respective levels of irrigation water salinity, a reduction of $-32.69 \%$.

According to the classification proposed by Maas \& Hoffmam (1977), sugarcane has a threshold salinity of 1.7 $\mathrm{dS} \mathrm{m}^{-1}$, being classified as moderately sensitive to salinity. However, based on the reduction in stem yield, the variety RB

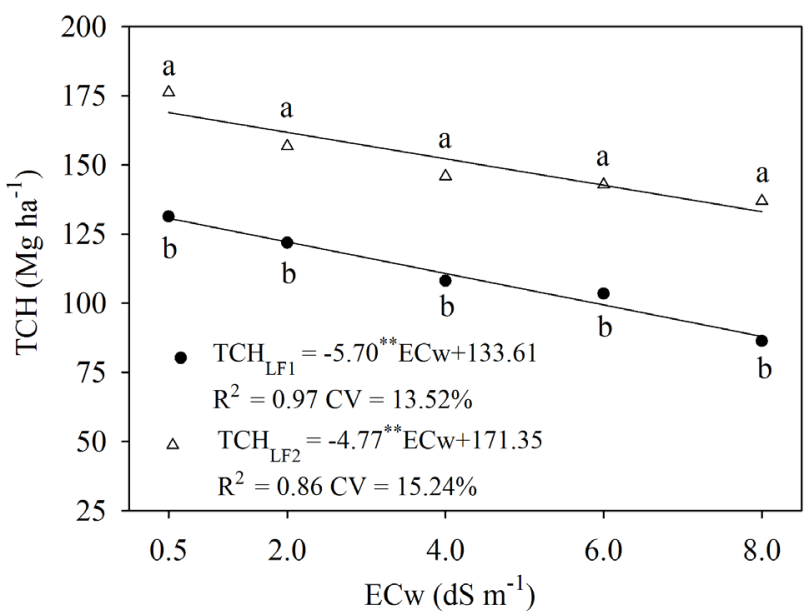

${ }^{* *},{ }^{*}$ - Significant at $\mathrm{p} \leq 0.01$ and 0.05 , respectively, by $\mathrm{F}$ test. Values with the same letters indicate not significant difference $(\mathrm{p} \leq 0.05)$ in the conditions without (LF1) and with (LF2) leaching fraction

Figure 5. Production of green mass of stems (TCH) of sugarcane (RB92579) subjected to water salinity and without (LF1) and with (LF2) leaching fraction
92579 was classified as moderately tolerant under both leaching conditions (LF1 and LF2), according to the classification of Fageria (1985).

Lira et al. (2018b) conducted a study in Recife, PE, Brazil, with the variety RB867515 under irrigation with brackish waters $\left(0.5\right.$ to $\left.6.5 \mathrm{dS} \mathrm{m}^{-1}\right)$, and observed a reduction of $28.64 \%$ in fresh matter yield, and the highest yield (116.60 $\left.\mathrm{Mg} \mathrm{ha}^{-1}\right)$ was obtained at the lowest level of salinity.

\section{Conclusions}

1. Increasing water salinity from $0.5 \mathrm{dS} \mathrm{m} \mathrm{m}^{-1}$ reduces leaf water potential and stem fresh matter yield.

2. The activity of the enzymes (catalase and ascorbate peroxidase) increased with the increment in water salinity levels at all ages of the plants, with higher values in plants irrigated using water with salinity from 6.07 to $7.27 \mathrm{dS} \mathrm{m}^{-1}$.

3. The leaching fraction of 0.17 increases the water status of plants and reduces the activity of antioxidant enzymes.

\section{ACKNOWLedgments}

The work was carried out with the support of the Coordenação de Aperfeiçoamento de Pessoal de Nível Superior - Brasil (CAPES) - Financing Code 001. And the Fundação de Amparo à Ciência e Tecnologia de Pernambuco (FACEPE) with the granting of the postgraduate scholarship and Conselho Nacional de Desenvolvimento Científico e Tecnológico (CNPq/ INCTsal) for financial support.

\section{Literature Cited}

Allen, R. G.; Pereira, P. S.; Raes, R.; Smith, M. Crop evapotranspiration: Guidelines for computing crop water requirements. Rome: FAO, 1998. 300p. Irrigation and Dranaige, Paper 56

Anitha, R.; Mary, P. C. N.; Savery, M. A. J. R; Sritharan, N.; Purushothaman, R. S. Differential responses of sugarcane (Saccharum officinarum L.) genotypes under salt stress condition. Plant Archive, v.15, p.1055-1060, 2015.

Azevedo, R. A.; Carvalho, R. F.; Cia, M. C.; Gratão, P. L. Sugarcane under pressure: An overview of biochemical and physiological studies of abiotic stress. Tropical Plant Biology, v.4, p.42-51, 2011. https://doi.org/10.1007/s12042-011-9067-4

Carvalho, M. F.; Correa, M. M.; Carvalho, G. C.; Rolim Neto, F. C.; Marinho, G. P. A.; Andrade, S. B. Atividade enzimática de três variedades de cana-de-açúcar sob estresse salino. Revista Brasileira de Engenharia Agrícola e Ambiental, v.20, p.806810, 2016. https://dx.doi.org/10.1590/1807-1929/agriambi. v20n9p806-810

Cavalcante, L. F.; Santos, C. J. O.; Holanda, J. S.; Lima Neto, A. J.; Souto, A. G. L.; Dantas, T. A. G. Produção de maracujazeiro amarelo no solo com calcário e potássio sob irrigação água salina. Irriga, v.23, p.727-740, 2018. https://doi.org/10.15809/ irriga.2018v23n4p727-740

Cavalcanti, F. J. A. Recomendações de adubação para o Estado de Pernambuco: Segunda aproximação. Recife: Instituto Agronômico de Pernambuco, 2008. 212p. 
CONAB - Companhia Nacional de Abastecimento. Acompanhamento da safra brasileira de cana-de-açúcar. Segundo Levantamento. Brasília: CONAB, 2018. 76p.

Dillewijn, C. V. Botany of sugarcane. Waltham: Chronica Botanica, 1952. 371p.

Endres, L.; Silva, J. V.; Ferreira, V. M.; Barbosa, G. V. de S. Photosynthesis and water relations in Brazilian sugarcane. The Open Agriculture Journal, v.4, p.31-37, 2010. https://dx.doi. org/10.2174/1874331501004010031

Fageria, N. K. Salt tolerance of rice cultivars. Plant and Soil, v.88, p.237-243, 1985. https://doi.org/10.1007/BF02182450

Fahad, S.; Bajwa, A. A.; Nazir, U.; Anjum, S. A; Farooq, A.; Zohaib, A.; Sadia, S.; Nasim, W.; Adkins, S.; Saud, S.; Ihsan, M. Z.; Alharby, H.; Wu, C.; Wang, D.; Huang, J. Crop production under drought and heat stress: Plant responses and management options. Plant Science, v.8, p.1-16, 2017. https://dx.doi.org/10.3389/fpls.2017.01147

Ferreira, D. F. Sisvar: A computer statistical analysis system. Ciência e Agrotecnologia, v.35, p.1039-1042, 2011. http://dx.doi. org/10.1590/S1413-70542011000600001

Ferreira, H. S. T.; Tusunada, S. M.; Bassi, D.; Araújo, P.; Mattiello, L.; Guidelli, G. V.; Righetto, G. L.; Gonçalves, V. R.; Lakshmanan, P.; Menossi, M. Sugarcane water stress tolerance mechanisms and its implications on developing biotechnology solutions. Frontiers in Plant Science, v.8, p.1-18, 2017. http://dx.doi.org/10.3389/ fpls.2017.01077

Herbert, E. R.; Boon, P.; Burgin, A. J.; Neubauer, S. C.; Franklin, R. B.; Ardón, M.; Hopfensperger, K. N.; Lamers, L. P. M.; Gell, P. A global perspective on wetland salinization: Ecological consequences of a growing threat to freshwater wetlands. Ecosphere, v.6, p.1-43, 2015. https://doi.org/10.1890/ES14-00534.1

Kar, M.; Mishra, D. Catalase, peroxidase, and polyphenoloxidase activities during rice leaf senescence. Plant Physiology, v.57, p.315-319, 1976. https://doi.org/10.1104/pp.57.2.315

Lira, R. M. de; Silva, Ê. F. de F. e; Barros, M. da S.; Gordin, L. C.; Willadino, L. G.; Barbosa, R. F. Water potential and gas exchanges in sugarcane irrigated with saline waters. Revista Brasileira de Engenharia Agrícola e Ambiental, v.22, p.679-682, 2018a. https:// doi.org/10.1590/1807-1929/agriambi.v22n10p679-682

Lira, R. M.; Silva, Ê. F. F.; Simões Neto, D. E.; Santos Júnior, J. A.; Lima, B. L. C; Silva, J. S. Growth and yield of sugarcane irrigated with brackish water and leaching fractions. Revista Brasileira de Engenharia Agrícola e Ambiental, v.22, p.170-175, 2018b. https:// dx.doi.org/10.1590/1807-1929/agriambi.v22n3p170-175
Maas, E. V.; Hoffman, G. J. Crop salt tolerance: Current assessment. Journal of Irrigation and Drainage Division of ASCE, v.103, p.115-134, 1977.

Mansour, M. M. F. The plasma membrane transport systems and adaptation to salinity. Journal of Plant Physiology, v.171, p.17871800, 2014. https://doi.org/10.1016/ j.jplph.2014.08.016

Munns, R.; Tester, M. Mechanisms of salinity tolerance. Annual Review of Plant Biology, v.59, p.651-681, 2008. https://doi. org/10.1146/annurev.arplant.59.032607.0

Nakano, Y.; Asada, K. Hydrogen peroxide is scavenged by ascorbatespecific peroxidase in spinach chloroplasts. Plant Cell Physiology, v.22, p.867-880, 1981. https://doi.org/10.1093/oxfordjournals. pcp.a076232

Negrão, S.; Schmöckel, S. M.; Tester, M. Evaluating physiological responses of plants to salinity stress. Annals of Botany, v.119, p.1-11, 2017. https://doi.org/10.1093/aob/mcw191

Nishiyama, Y.; Murata, N. Revised scheme for the mechanism of photoinhibition and its application to enhance the abiotic stress tolerance of the photosynthetic machinery. Applied Microbiology and Biotechnology, v.98, p.8777-8796, 2014. https://doi. org/10.1007/s00253-014-6020-0

Oliveira, H.; Nascimento, R.; Silva, S.; Cardoso, J. A. F.; Guimarães, R. F. B.; Nascimento, E. C. S. Initial growth and gas exchanges of plants of colored Cotton submitted to saline stress. Agricultural Sciences, v.9, p.1652-1663, 2018. https://doi.org/10.4236/ as.2018.912115

Puga, A. P.; Melo, L. C. A.; Abreu, C. A.; Coscione, A. R.; Paz-Ferreiro, J. Leaching and fractionation of heavy metals in mining soils amended with biochar. Soil and Tillage Research, v.164, p.25-33, 2016. https://doi.org/10.1016/j.still.2016.01.008

Richards, L. A. Diagnosis and improvement of saline and alkali soils. Washington: U.S. Department of Agriculture, 1954. 160p.

Soil Survey Staff. Keys to soil taxonomy (12. ed.). Washington, DC: United States Department of Agriculture, Natural Resources Conservation Service, 2014. 372p.

Taiz, L.; Zeiger, E.; Møller, I. M.; Murphy, A. Fisiologia e desenvolvimento vegetal. 6.ed. Porto Alegre: Artmed, 2017. 858p.

Zhang, Z.; Xu, Y.; Xie, Z.; Li, X.; He, Z.; Peng, X. Associationdissociation of glycolate oxidase with catalase in rice: A potential switch to modulate intracellular $\mathrm{H}_{2} \mathrm{O}_{2}$ levels. Molecular Plant, v.9, p.737-748, 2016. https://doi.org/10.1016/j.molp.2016.02.002 